\title{
THE PROFILE OF VAGINAL TEMPERATURE AND CYTOLOGY OF VAGINAL SMEAR IN BALI CATTLE DURING ESTRUS CYCLE PHASE
}

\author{
Indira P.N., Kustono and Ismaya \\ Master Program of Animal Science, Department of Animal Physiology and Reproduction, \\ Faculty of Animal Science, Gadjah Mada University, \\ Jl Fauna No 3 Karangmalang, Yogyakarta - Indonesia \\ Corresponding E-mail: indira.putri.n@mail.ugm.ac.id
}

Received July 04, 2014; Accepted August 27, 2014

\begin{abstract}
ABSTRAK
Penelitian ini bertujuan untuk mengevaluasi kondisi fisiologis sapi Bali selama birahi. Sembilan ekor sapi Bali digunakan dalam penelitian sebagai sampel. Metode deskriptif digunakan dalam penelitian ini. Pengukuran suhu vagina dilakukan dengan termometer digital dan sitologi vagina dengan bantuan cottonbud yang diusapkan pada glass objek. Sampel smear vagina diwarnai dengan pewarnaan Giemsa yang selanjutnya diamati dengan menggunakan mikroskop. Hasil penelitian menunjukkan bahwa suhu vagina adalah $38,39 \pm 0,29{ }^{\circ} \mathrm{C} ; 38,05 \pm 0,15{ }^{\circ} \mathrm{C} ; 37,4 \pm 0,74{ }^{\circ} \mathrm{C} ; 37,86 \pm 0,3{ }^{\circ} \mathrm{C}$ yang meliputi fase diestrus, metestrus, diestrus, dan proestrus. Berdasarkan sitologi vagina smear, fase estrus memiliki lebih banyak sel kornifikasi superfisial dan sel intermediate yang menyebabkan konsentrasi estrogen meningkat. Berdasarkan hasil analisis profil suhu vagina, dapat disimpulkan bahwa sitologi dari vagina smear setiap jenis fase siklus estrus memiliki karakteristik sendiri dan pada gambaran setiap sel terdapat perbedaan fase siklus estrus.

Kata kunci: sapi Bali, siklus estrus, sitologi vagina smear, suhu
\end{abstract}

\begin{abstract}
The objective of the study was to evaluate physiological condition of Bali cattle during estrus. Nine cattles were used in the research. The method of the research was descriptive analysis. The measurement of vaginal temperature was conducted by using digital thermometer and cytology of vaginal smear was done by using cotton bud swabbed on object glass. It was washed by methanol and was stained with Giemsa staining and was observed by microscope. The results indicated that vaginal temperature were $38.39 \pm 0.29{ }^{\circ} \mathrm{C} ; 38.05 \pm 0.15{ }^{\circ} \mathrm{C} ; 37.4 \pm 0.74{ }^{\circ} \mathrm{C} ; 37.86 \pm 0.3{ }^{\circ} \mathrm{C}$ at estrus, metestrus, diestrus, proestrus phase, respectively. On the basis of the cytology of vaginal smear, estrus phase had more superficial cornification and intermediate cells causing estrogen concentration increased. In conclusion, the profile of vaginal temperature showed that each kind of estrus cycle phase had characteristic within estrus. The cytology of vaginal smear showed various types of cells preferences in different phase of estrus cycle.

Keywords: Bali cattle, estrus cycle, temperature, cytology vaginal smear
\end{abstract}

\section{INTRODUCTION}

Bali cattle is potential and popular for developing germplasm in Indonesia because they have high productivity not only carcass but also body weight. Bali cattle has special genetic that is easy to adapt to bad environment. It was stated by Handiwirawan and Subandriyo (2007), Bali cattle were called pioneer cattle from the aspect of reproduction, Bali cattle has high fertility rate, which is about $83-86 \%$.

Currently, Bali cattle has some problems such as genetic decline, high inbreeding, low adaptation (Sariubang et al., 1998) Low estrus detection efficiency is known as one of the main causes of poor fertility rate of Bali cattle (Noor et 
al., 2002). This lead to prolonged calving interval and calving to conception intervals, and also to low herd technical and economic performance, even in developed countries (Bage et al., 2002). This situation results of poor reproductive practices that commonly observed in livestock production systems in the tropics as well as in Indonesia (Hardjopranjoto, 1995).

Visual methods for estrous detection are well documented, but method usage and their efficiency are still controversial (Fahey et al., 2002). The silent heat of Bali cattle is a supplementary difficulty to visual estrus detection (Salem et al., 2006). Hormones profile monitoring appear to be very expensive for low income livestock production systems (Wattemann et al., 2003). Cytology vaginal smear changes during estrus cycle have been studied in sheep (Bearden et al., 2004), but little is known about this issue in cattle, especially in Bali cattle. On the basis of those reason, a research contribute to heat detection efficiency by evaluating cytology vaginal smear combined to vaginal temperature changes during estrus cycle were conducted. It can protect the cattle from repeating breeding. This research was aimed to help animal farm and researcher to know more about the physiological condition of Bali cattle during estrus. It was expected that this study will increase the success of breeding of Bali cattle for both natural and insemination.

\section{MATERIALS AND METHODS}

\section{Materials}

Nine cattles were used in the research which was 3 years old with average body weight of $313.67 \pm 20.66 \mathrm{~kg}$. The cattles were fed elephant grass and polar concentrate. The cattle drank mineral water added with ad-libitum.

\section{Procedures}

The measurement of vaginal temperature was conducted by using digital thermometer (length of 3 to $5 \mathrm{~cm}$ ) until constant temperature was obtained. Before and after the measurement of temperature, thermometer was sterilized using cotton added with $70 \%$ of alcohol. The cotton bud was used for wrapping of cytology vaginal smear from vaginal epithelia tissues into object glass. The object glass was then stained with Giemsa method for 30 to 45 minutes. After being dried, it was observed by the microscope.

\section{Data Analysis}

The vaginal temperature was analyzed by using SPSS ver 20 program for Windows $\left(\mathrm{IBM}^{\circledR}\right.$, 2012). Cytology of vaginal smear was analyzed descriptively according to method of Astuti (2007).

\section{RESULTS AND DISCUSSION}

The vaginal temperature of nine Bali cattles are presented the Table 1. The table showed that the vaginal temperature ranged from $37.4{ }^{\circ} \mathrm{C}$ to $38.39{ }^{\circ} \mathrm{C}$ within estrus cycle phase. The highest temperature was in estrus phase. Kyle et al. (1998) reported that in their research, vaginal temperature gradually decreased many days before estrus and it increased during estrus phase. The vaginal temperatures were changed because of the effect of hormonal system. The hormone system of ovarium especially estrogen and luteinizing can create blood vascularization around genital organ on increasing reproduction. Thus, the thermals were streamed by bloods and vaginal temperatures increased because of vascularization process (Hovinen et al., 2008). Estrus cycle phase was affected by hormonal change that happened during ovulation with the increase of the luteinizing hormone on bloods. Acosta et al. (2003) also reported the significant correlation between estradiol plasma concentration and luteinizing hormone which increased the vascularization within preovulation cycle on cattle. Other factors were vaginal mucus that was changed within estrus cycle (Rorie et al., 2002). However, this research was still difficult to compare with other different treatments or qualitative research. In addition, many animals had the highest variation on measurement (Lehrer et al., 1995).

The wrapping method of vaginal smear used Giemsa staining method to find out estrus cycle. The result of vaginal smear is presented in Figure

Table 1. The Vaginal Temperature of Bali Cattles

\begin{tabular}{lc}
\hline Phase & Vaginal Temperature $\left({ }^{\circ} \mathrm{C}\right)$ \\
\hline Diestrus & $37.40 \pm 0.74$ \\
Proestrus & $37.86 \pm 0.30$ \\
Estrus & $38.39 \pm 0.29$ \\
Metestrus & $38.05 \pm 0.15$ \\
\hline
\end{tabular}


1. It can be seen in Figure 1 that the difference of cells in each phase and estrus phase was marked by many superficial cells and intermediate cells. Vaginal epithelial cells proportions recorded during estrous phases was similar to report of Marondes et al. (2002). The epithelium of vagina was sensitive for estradiol $17-\beta$ concentration during its development. The receptor of estradiol $17-\beta$ can be obtained on vagina tissues (Bologna, 2001). The part of vaginal epithelium consisted of four cells type where almost three cells on vaginal epithelium always had cornification that were parabasal cell, intermediate cell and superficial cell. However, cornification of basal cell only happened during trauma and radiation (Bologna, 2001). Intermediate and parabasal cells were indicated by vaginal smear on metestrus, diestrus, and proestrus phase. Perez et al. (2009) reported that superficial parabasal cells were specifically marked to detect the activity of ovarium before puberty. Similar finding was also reported by Schuttle (2010) stating that superficial cells in vaginal smear were specifically marked for the condition of estrogen hormone. Superficial cells were found on vaginal smear during estrus phase while estrogen concentration was increased (Junaidi, 2005). Superficial cells came out of basal membrane and they developed than other cells. Thus, this cells were mature because of cornification after development process stimulated by estradiol 17- $\beta$ (Bologna, 2001). Mehta et al. (2000) reported that changing steroid hormone is related with vaginal smear's changes. This was supported by Garofalo and Tasendo (2000) who stated about the effect of estradiol 17$\beta$ hormone and the cytology of vaginal smear,

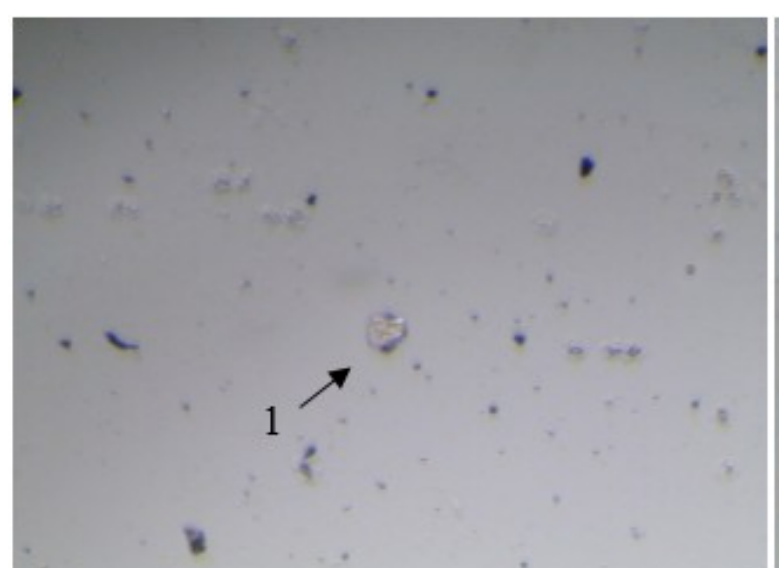

A. Diestrus

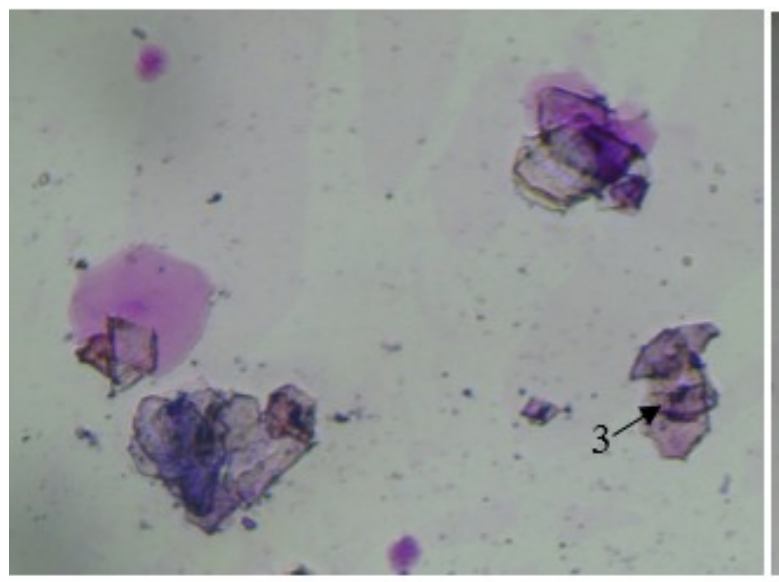

C. Estrus

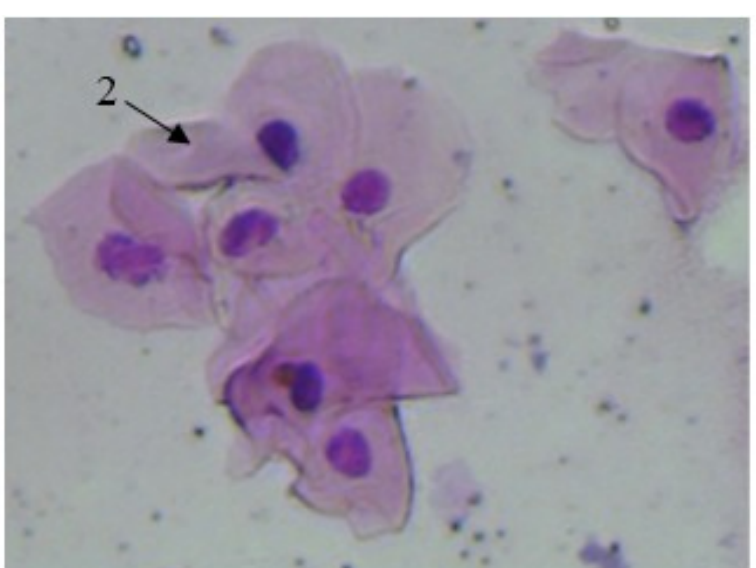

B. Proestrus

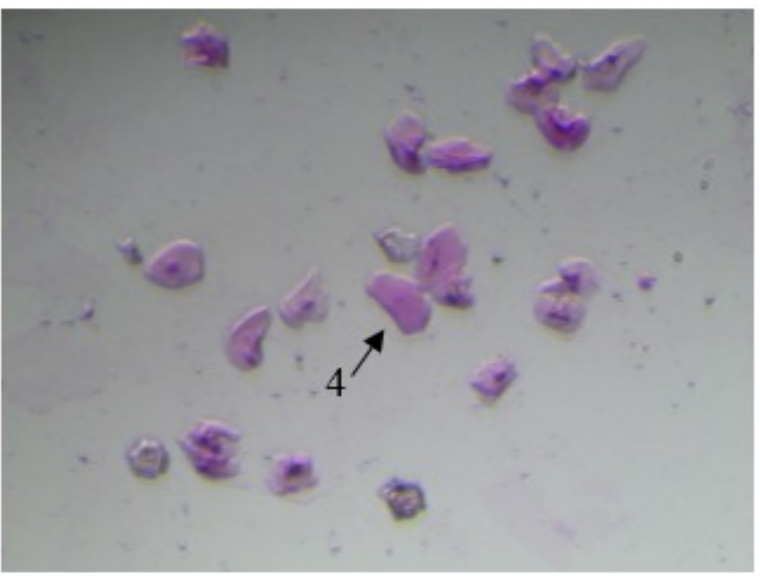

D. Metestrus

Figure 2. The citology of Vaginal Smear with Giemsa Stain during Estrus Cycle Phase in Bali Cattle. 1:Leukocyte, 2: Superficial cell, 3: Intermediate cell, 4: Parabasal cell 
which is typically similar with estrus behavior.

\section{CONCLUSION}

Vaginal temperature gave complete information about physiology within estrus cycle phase and the cytology of vaginal smear can explain that estrus phase had more superficial cornification and intermediate cells.

\section{ACKNOWLEDGEMENT}

The authors would like to highly appreciate to the chair of Field for Education, Research, and Farming Development, Gadjah Mada University for giving permission to use animals and barn facilities during this research. The present research is granted and funded by Indonesian Endowment Fund for Education, Ministry of Finance, Republic of Indonesia.

\section{REFERENCES}

Acosta, T.J., K.G. Hayashi, M. Mohtani and A. Miyamoto. 2003. Local changes in blood flow within the preovulatory follicle wall and early corpus luteum in cows. Reproduction. 125:759-767

Astuti, M. 2007. Pengantar ilmu statistik untuk peternakan dan kesehatan hewan. Binasti Publisher. Bogor.

Bage, R., H. Gustafsson, B. Larsson, M. Forsberg and H. Rodriguez-Martinez. 2002. Repeat breeding in dairy heifers: Follicular dynamics and oestrous cycle characteristic in relation to sexual hormone patterns. Theriogenology 57:2257-2269

Bearden, H.J., J.W. Fuquay and S.T. Willard. 2004. Applied Animal Reproduction. $6^{\text {th }}$ ed. Pearson Prentice Hall,USA.

Bologna, J.W. 2001. Genitourinary problems associated with menopause. Anim. Reprod. Sci. 90:51-55

Fahey, J., K. O'Sullivan, J. Crilly and J.F. Mee. 2002. The effect of feeding and management practices on calving rate in dairy herds. Anim. Reprod. Sci. 74:133-150

Garofalo, E. G. and C. Tasendo. 2000. Uterine estrogen and progesterone reseptors in prepubertel ewes: distribution in myometrium, endometrium and caruncle. Vet. Res. 27:177-183

Handiwirawan, E. and Subandriyo. 2007. Perbaikan Mutu Genetik Sapi Bali. Balai
Penelitian Ternak. Bogor.

Hardjopranjoto, H.S. 1995. Ilmu kemajiran ternak. Airlangga University Press, Surabaya.

Hovinen, M., J. Silvonene, S. Taponen, L. Hanninen, M. Pastell, A. M. Aisla and S. Pyorala. 2008. Detection clinical mastitis with the help of a thermal camera. J. Dairy Sci. 91:4592-4598

IBM $^{\circledR}$. 2012. SPSS Statistics Editions. IBM Corporation Software Group. United States America.

Junaidi, A. 2005. Reproduksi dan obstetri pada anjing. Gadjah Mada University Press. Yogyakarta.

Kyle, B.L., A.D. Kennedy and J.A. Small. 1998. Measurement of vaginal temperature by radioelementary for the prediction of estrus in beef cows. Theriogenology 49:1437-1449

Lehrer, A.R., Lewis, G.S., Mc Millan, W.H. and E. Aizinbud. 1995. Bio-impedance monitoring of genital tissues of cows as an aid in cattle reproductive management-a review. Proceedings of the New Zealand Society of Animal Production 55:221-223

Marcondes, F.K., F.J., Bianchi and A.P. Tanno. 2002. Determination of the estrous cycle phase of rats: some helpful considerations. J. Brazilian Archiv. Biol. Technol. 4(A):600614

Mehta, R. R., J.M. Jenco, L.V. Gaynor and R.T. Jr. Chartterton. 2000. Relationships between ovarian morphology, vaginal cytology, serum progesterone, and urinaria immunoreactive pregnanediol during the menstrual cycle of the cyanomolgus monkey. Biol. Reprod. 47:408-417

Noor, R. R, A. Farajallah and M. Karmita. 2002. Pengujian kemurnian sapi Bali dengan analisis hemoglobin dengan metode Isoelectric Focusing. Hayati 8: 107-111

Perez, M., Mendoza, M. E. and M.C. Romano. 2009. Exfoliative vaginal cytology and plasma levels of estrone and oestradiol 17 in young and adult goats. Small Rum. Res. 33:153-158

Rorie, R.W., T.R. Bilby and T.D. Lester. 2002. Application of electronic estrus detection technologies to reproductive management of cattle. Theriogenology 57:137-148

Salem, M.B., M. Djemali, C. Kayouli and A. Majdoub. 2006. A review of environmental and management factors affecting the reproductive performance of Holstein- 
Friesian dairy herds in Tunisia. Livest. Res. 18(4):123-129

Sariubang, M., D. Pasambe and Chalidjah. 1998.

Pengaruh kawin silang terhadap performa hasil turunan pertama (F1) pada sapi Bali di Sulawesi Selatan. Prosiding Seminar Nasional Peternakan dan Veteriner, Bogor. June 19-20, 1998. P. 731-737
Schuttle, A.P. 2010. Technique and cytology morphology. J. Small. Anim. Pract. 18:301306

Wattemann, R.P., C.A. Lents, N.H., Ciccioli, F.J. White and I. Rubio. 2003. Nutritional and suckling-mediated anovulation in beef cows. J. Anim.Sci. 81 (E. Suppl.2):E48-E59 